\title{
Gastric autonomic nerve tumour: a rare gastric tumour
}

\author{
Ahmed Abbas, Ali Al-Arini, Abdul-Wahed Nasir Meshikhes
}

Department of Surgery, King Fahad Specialist Hospital, Dammam, Eastern, Saudi Arabia

\section{Correspondence to} Dr Abdul-Wahed Nasir Meshikhes,

meshikhes@gmail.com

Accepted 25 March 2014

\section{DESCRIPTION}

A 37-year-old woman presented with vague upper abdominal pain and dyspepsia. Clinical examination was unremarkable. Gastroscopy showed a smooth 'bulge' at the junction of the gastric body and fundus along the greater curvature with normal overlying mucosa. Biopsy revealed inflammatory changes but no dysplasia or malignancy. CT scan showed welldefined gastric body wall mass (figure 1). She underwent a wedge resection of the mass with normal gastric margin without regional lymphadenectomy.

Histopathology showed a well-circumscribed lesion $(4.5 \times 3.0 \mathrm{~cm})$ composed of spindled cells arranged in interlacing fascicles, whorls and palisades (figure 2). Very rare mitoses (1/50 HPF) were seen and the overlying mucosa was normal. The appearance was those of gastric autonomic nerve

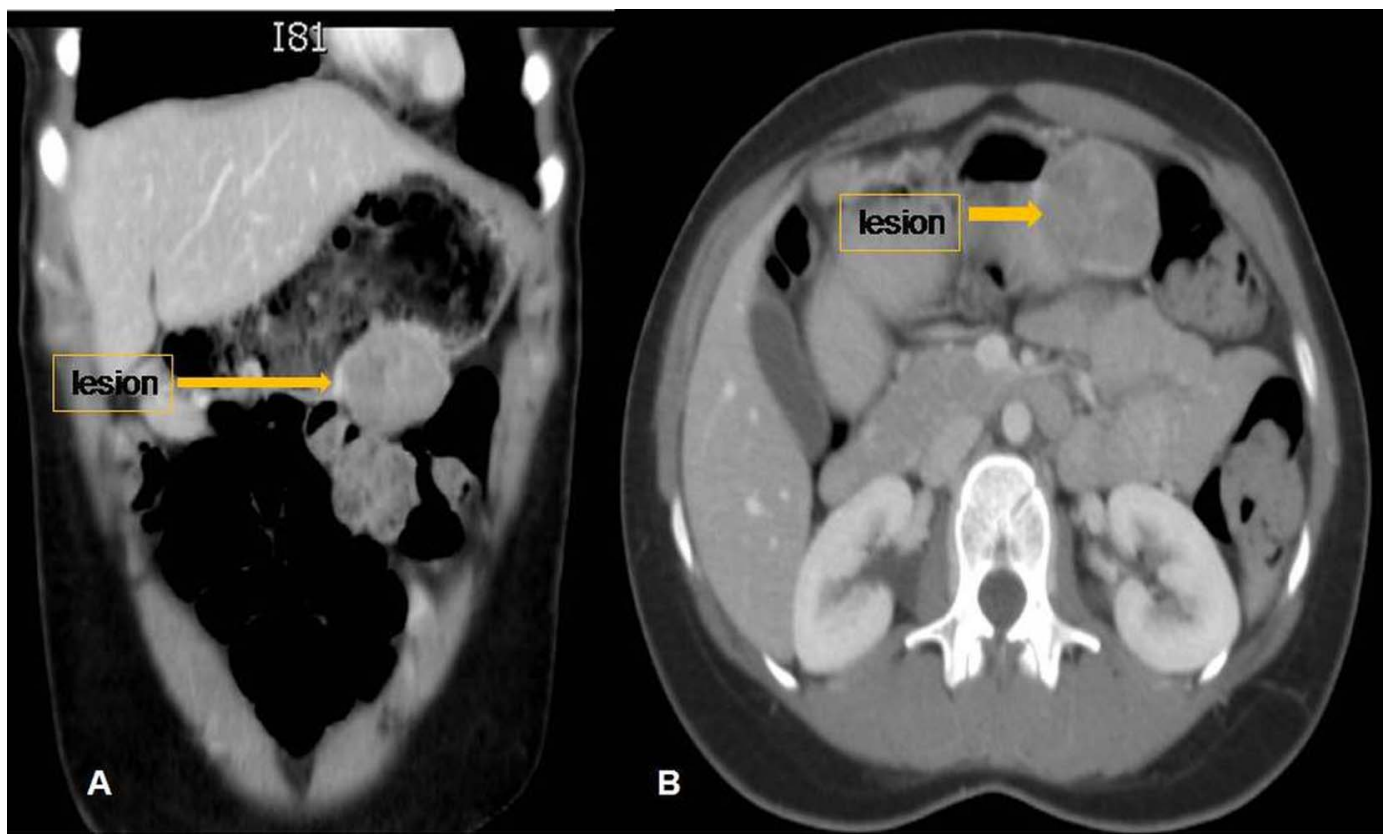

Figure $1 \mathrm{CT}$ scan (A, coronal and B, axial views) demonstrating well-defined rounded heterogeneous exophytic mass lesion in the greater curvature of the stomach with no associated lymphadenopathy.

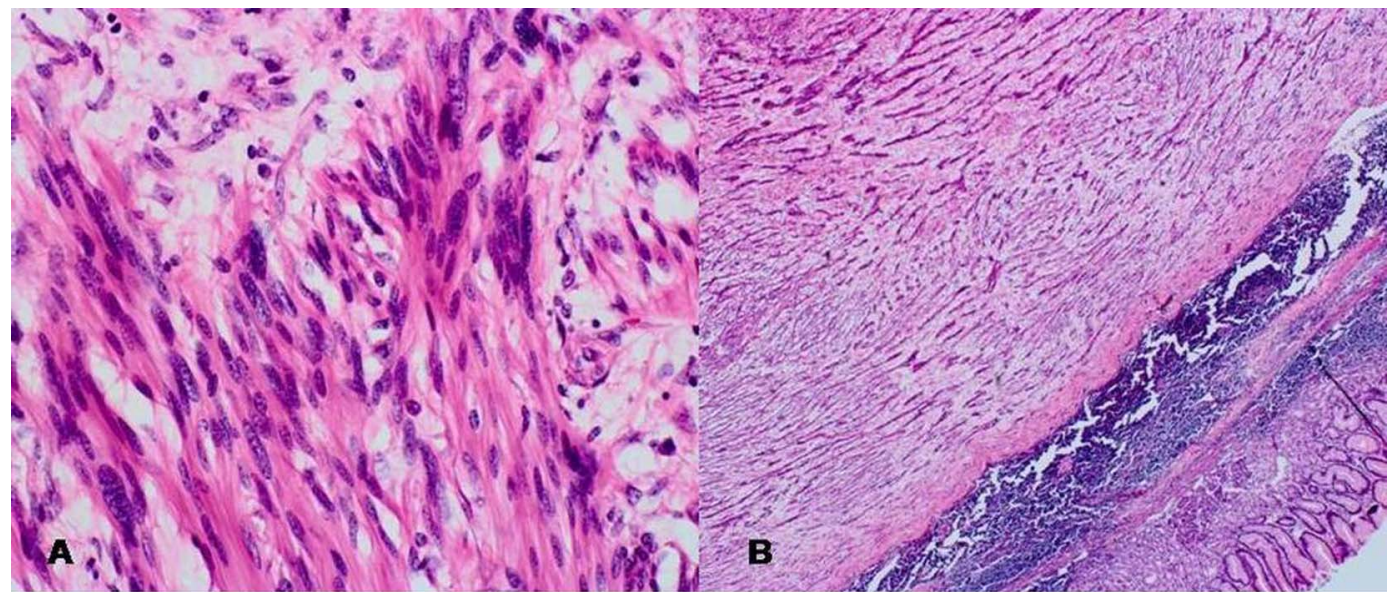

To cite: Abbas A,
Al-Arini A, Meshikhes A-WN. BMJ Case Rep Published online: [please include Day Month Yearl doi:10.1136/bcr2014-204638

Figure 2 High-power histomicrograph showing bland spindle cell nuclei with occasional large hyper chromatic nuclei with very rare mitoses and no necrosis $(A)$. High-power photography, which shows the neoplasm as composed of spindle cells arranged in interlacing fascicles, whorls and palisades (B; H\&E stain). 
tumour (GANT). This was confirmed by immunohistochemistry. The patient remained well with no evidence of local recurrence or metastases at 5-year follow-up.

GANTs arise from the autonomic nerve plexuses. They are extremely rare accounting for $1 \%$ of all malignant gastrointestinal tumours. They occur at any age, but most commonly in younger patients. ${ }^{1}$ Histologically, they resemble other gastrointestinal stromal tumours. ${ }^{2}$ The diagnosis is made on electron microscopy and immunohistochemistry. ${ }^{3}$ Although considered benign, they are slowly growing with an aggressive clinical course and poor prognosis that leads to death. ${ }^{3}$ However, like

\section{Learning points}

Gastric autonomic nerve tumours are extremely rare that arise from the autonomic nerve plexuses.

- The diagnosis is often made by electron microscopy and immunohistochemistry.

- Although considered benign tumours, gastric autonomic nerve tumour may run an aggressive course with poor prognosis even after radical surgical resection. this case, GANT may run a benign course if it exhibits rare mitotic figures. Surgical resection offers the only chance of cure as the response to chemotherapy and radiotherapy is ineffective. However, in spite of radical excision, patients die a few months after surgery with local recurrences and distant metastases to lymph nodes, liver and bones. ${ }^{4}$

Contributors AA wrote the initial draft and searched the literature. AA-A performed the surgery and participated in drafting the manuscript. A-WNM searched the literature and wrote the final draft.

Competing interests None.

Patient consent Obtained.

Provenance and peer review Not commissioned; externally peer reviewed.

\section{REFERENCES}

1 MacLeod CB, Tsokos M. Gastrointestinal autonomic nerve tumor. Ultrastruct Pathol 1991;15:49-55.

2 Pinedo Moraleda F, Martínez González MA, Ballestín Carcavilla C, et al. Gastrointestinal autonomic nerve tumours: a case report with ultrastructural and immunohistochemical studies. Histopathology 1992;20:323-9.

3 Shanks JH, Harris M, Banerhee SS, et al. Gastrointestinal autonomic nerve tumours: a report of nine cases. Histopathology 1996;29:111-21.

4 Meshikhes AW, Al-Garni AA, Al-Momen SA, et al. Gastrointestinal autonomic nerve tumor of the stomach. Am J Case Rep 2014:15:7-12.

Copyright 2014 BMJ Publishing Group. All rights reserved. For permission to reuse any of this content visit

http://group.bmj.com/group/rights-licensing/permissions.

BMJ Case Report Fellows may re-use this article for personal use and teaching without any further permission.

Become a Fellow of BMJ Case Reports today and you can:

- Submit as many cases as you like

- Enjoy fast sympathetic peer review and rapid publication of accepted articles

- Access all the published articles

- Re-use any of the published material for personal use and teaching without further permission

For information on Institutional Fellowships contact consortiasales@bmjgroup.com

Visit casereports.bmj.com for more articles like this and to become a Fellow 